
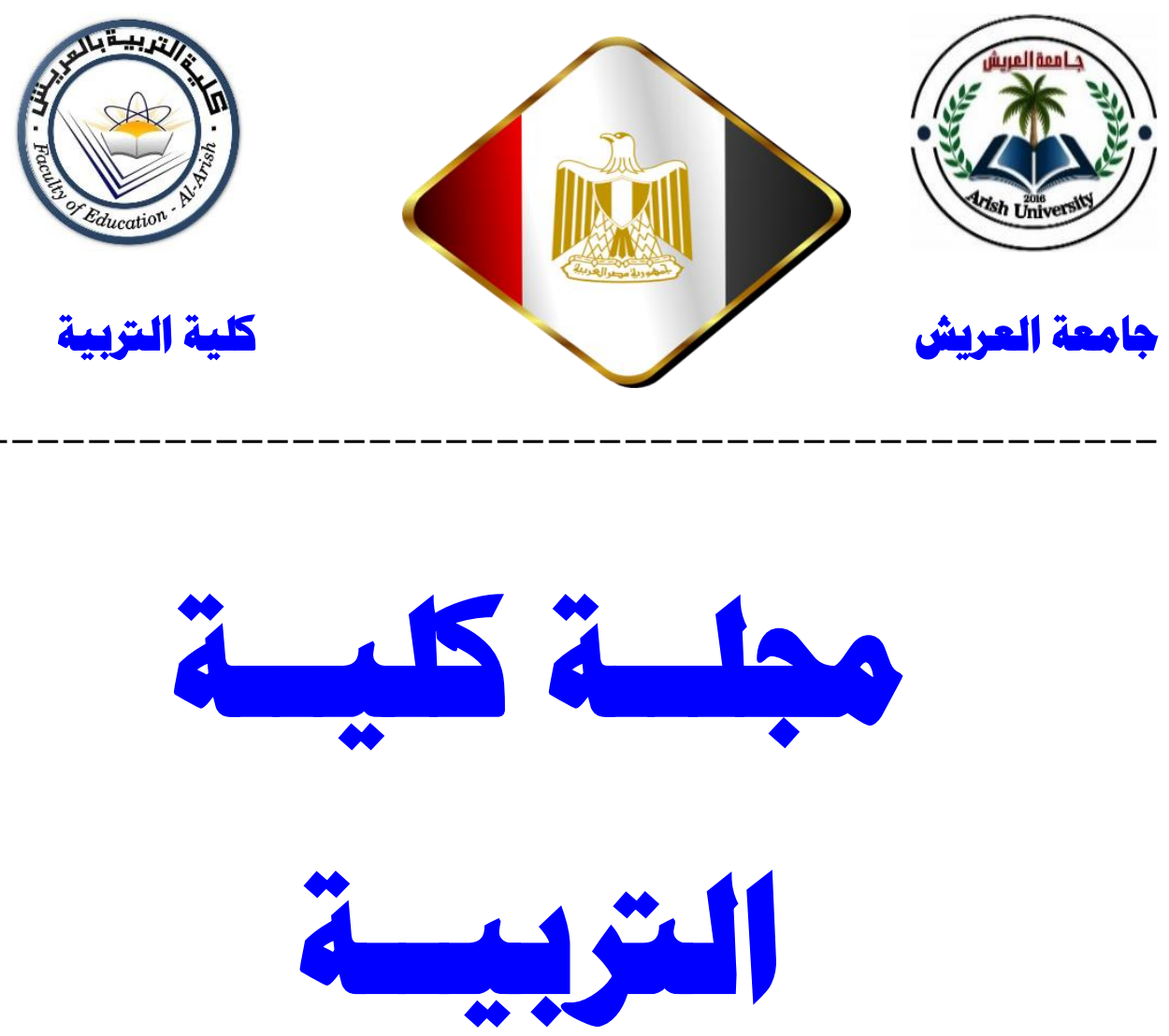

علمية محكمة ربع سنوية

(السنة السادسة - العدد السادس عشر -أكتوبر ^| •؟م)

j_foea@aru.edu.eg 
الإشراف الع

\begin{tabular}{|c|c|}
\hline (رئيس مجلـد الكلية & أ.د. رفعت عمر عزوز \\
\hline وكيل الكلية للاراسات العليا والبحوث & أ.د. السيد كامل الشرينح \\
\hline
\end{tabular}

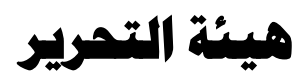

\begin{tabular}{|c|c|}
\hline رئيس التحريز & أ.د. محمد رجب فضل الله \\
\hline مدير التحرير & أ.د. أحمد عبد العظيم سالم \\
\hline عضو & د. كمال طاهر موسى \\
\hline عضو & د. أسماء حسن صبًاح \\
\hline
\end{tabular}

\section{الإشراف المالي والإداري}

\begin{tabular}{|l|l|}
\hline أ. محمد إبراهيم محمد عربيي أسماء محمد علي الثاعر المسؤول المالي \\
\hline أمسؤول الإداري
\end{tabular}




\section{قواعد النشر بمجة كلية التربية بالعريش}

ا. تتشر المجلة البحوث والدراسات التي تتوافر فيها الأصالة والمنهجية السليمة على ألا يكون

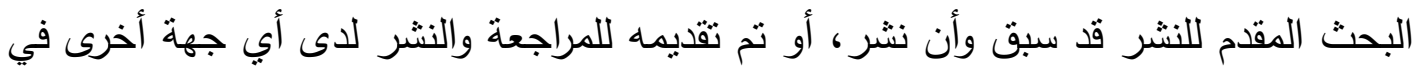
نفس وقت تقديمه للمجلة.

r. تُقبل الأبحاث المقدمة للنشر بإحدى اللغتين: العربية أو الإنجليزية.

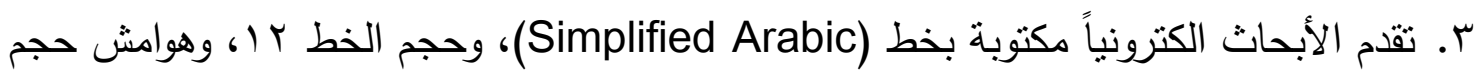
الواحد منها ه.r.بم، مع مراعاة أن تتسق الفقرة بالتساوي ما بين الهامش الأيسر والأيمن وهن (Justify) . وترسل إلكترونياً على شكل ملف (Microsoft Word). ء. يجب ألا يزيد عدد صفحات البحث المُحكم بما في ذلك الأشكال والرسوم والمراجع والجداول والملاحق عن (ro) صفحة. (الزيادة بحد أقصى ، (1 صفحات برسوم إضافية). ولا يزيد البحث المُستل عن ( • r صفحة ) (الزيادة بحد أقصى م صفحات برسوم إضافية). هـ يقلم الباحث ملخصاً لبحثه في صفحة واحدة، تتضمن الفقرة الأولى ملخصاً باللغة العربية، والفقرة الثانية ملخصاً باللغة الإنجليزية، وبما لا يزيد عن .. ب كلمة لكل منها. 7 . يكتب عنوان البحث واسم المؤلف والمؤسسة التي يعمل بها على صفحة منفصلة ثم يكتب عنوان البحث مرة أخرى على الصفحة الأولى من البحث. V. يجب عدم استخدام اسم الباحث في متن البحث أو قائمة المراجع ويتم استبدال الاسم بكلمة

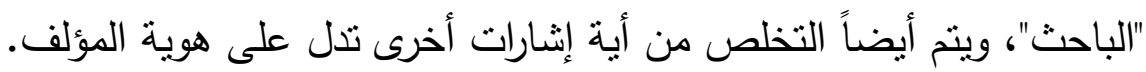

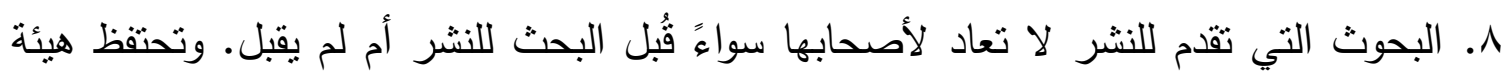
التحرير بحقها في تحديد أولويات نشر البحوث. 9 . لن ينظر في البحوث التي لا تتفق مع شروط النشر في المجلة، أو تلك التي لا تشمل على ملخص البحث في أي من اللغتين، أو يزيد عدد صفحاتها عن هب صفحة شاملة الصفحات

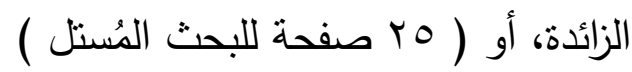
• 1. يقوم كل باحث بنسخ وتوقيع وإرفاق إقرار المواققة على اتفاقية النشر . 
11 ( بسهم الباحث في تكاليف نشر بحثه، ويتم تحويل التكلفة على الحساب الخاص بالمجلة. يجب إرسال صورة عن قسيمة التحويل أو دفع المبلغ، مع البحث الكترونيا. التكاليف تشمل: مكافأة

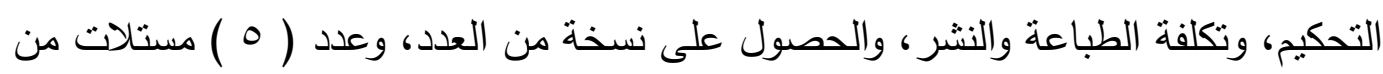

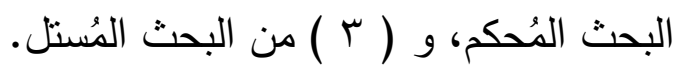
ب ا. يتم نشر البحوث أو رفض نشرها في المجلة بناءً على تقاربر المحكمين، ولا يسترد المبلغ في حالة رفض نشر البحث من قبل المحكمين. سا. يُمنح كل باحث إفادة بقبول بحثه للنشر بعد إتمام كافة التصويبات والتعديلات المطلوبة، وسداد الرسوم المقرة.

\section{قواعد التمكيم بمبلة كلية التثبهية بالمريشي}

فيما يلي القواعد الأساسية لتحكيم البحوث المقدمة للنشر بمجلة كلية التربية بالعريش

\section{القواعد عامهة:}

1. ـ مدى ارتباط موضوع البحث بمجال التربية. r. مدى مناسبة الدراسات السابقة، وإبرازها لرؤى متعددة.

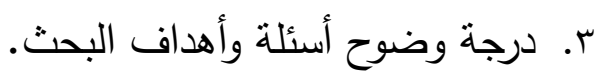

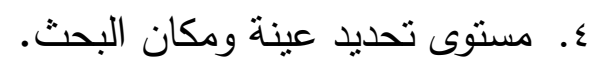
ه. درجة إتباع البحث لمعايير التوثيق المحددة في دليل رابطة علم النفس الأمريكية، العدد السادس.

ا. احتواء قائمة المراجع على جميع الدراسات المذكورة في منن البحث والعكس أيضاً

صحيح.



^. سلامة تقرير البحث من الأخطاء اللغوية المتعلقة بالنحو والإملاء وكذا المعنى. 9. تكامل جميع أجزاء تقرير البحث، وترابطها بشكل منطقي.

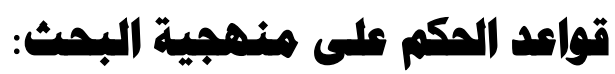
ا. تحديد الفترة الزمنية للبحث. 
r. تحديد منهجية مناسبة للبحث. r. تبرير إجراءات للاختيار في حالة دراسة الأفراد أو الجماعات. ء. تضمين البحث إطاراً نظرياً واضحاً. ه. توضيح الإجراءات المتعلقة بالجوانب المهنية الأخلاقية منل: الحصول على موافقة

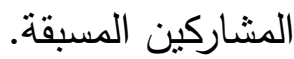

\section{قواعد تمكيم الإبمراكات:}

1. شرح وسائل جمع المعلومات بوضوح، والعمليات المتبعة فيها. r. تحديد وشرح المتغيرات المختلفة.

r. نترقيم جميع الجداول والأشكال والصور والرسوم البيانية بشكل مناسب وتبوييها والتأكد من سلامتها. ع. شرح عملية التحليل المتبعة ومبرراتها، والتأكد من اكتمالها وسلامتها. قواعد الهكم على النتاجه:

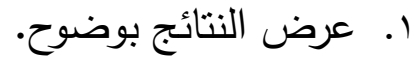

r. توضيح جوانب الاختلاف في حالة تعارض نتائج البحث مع نتائج الدراسات السابقة. r. اتساق الخاتمة والتوصيات مع نتائج البحث. 


\section{همتويات العدد ( 17 )}

\begin{tabular}{|c|c|c|c|}
\hline \multicolumn{2}{|c|}{ هيئة التحرير } & \multicolumn{2}{|l|}{ قيادة ودماء بداسيدة ثابتة ... قيم } \\
\hline |لهشمات & الباجش & & \\
\hline \multicolumn{4}{|c|}{ مةال اللمدف } \\
\hline $13-46$ & 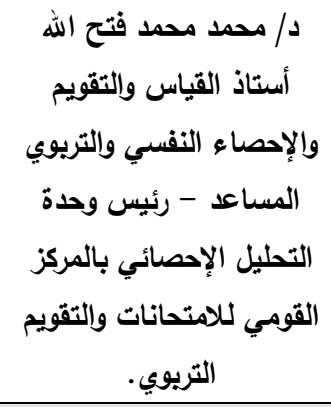 & 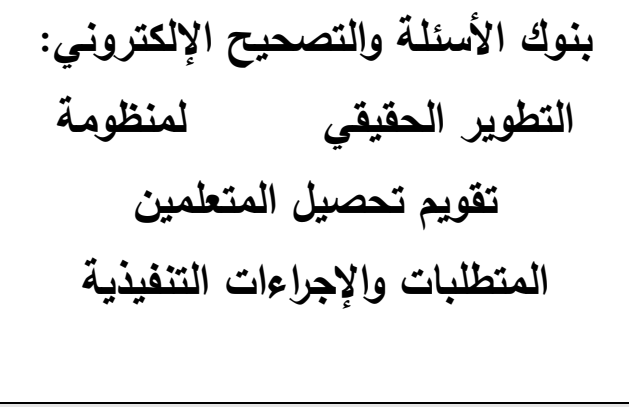 & \\
\hline \multicolumn{4}{|c|}{ بموث ودراسات همكمة } \\
\hline $49-96$ & 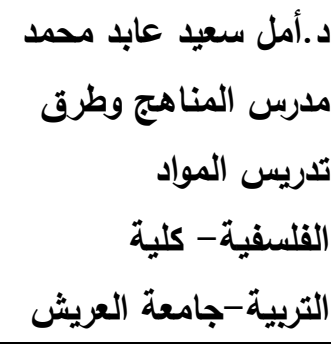 & في تثمية مهارات التسامد استراتيجية حوض السمك الفكري لاتى & 1 \\
\hline $97-134$ & $\begin{array}{l}\text { Dr. Mahdi M. A. } \\
\text { Ibrahim } \\
\text { Assistant Professor } \\
\text { ،of TEFL } \\
\text { Dept. of Curriculum } \\
\text { \& Instruction } \\
\text { Faculty of } \\
\text { Education, Arish } \\
\text { University }\end{array}$ & $\begin{array}{l}\text { The Effectiveness of Using } \\
\text { the SCAMPER Model in } \\
\text { Enhancing EFL Learners' } \\
\text { Essay Writing Skills and } \\
\text { their Attitudes towards it }\end{array}$ & $r$ \\
\hline
\end{tabular}




\begin{tabular}{|c|c|c|c|}
\hline $\begin{array}{c}135- \\
185\end{array}$ & مدمد دينا محمد أحمد & من ذالفروق في جودة الحياة لادى الطلاب & r \\
\hline & & & \\
\hline $\begin{array}{l}189- \\
222\end{array}$ & 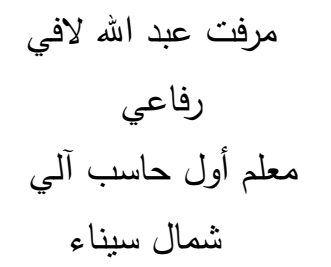 & 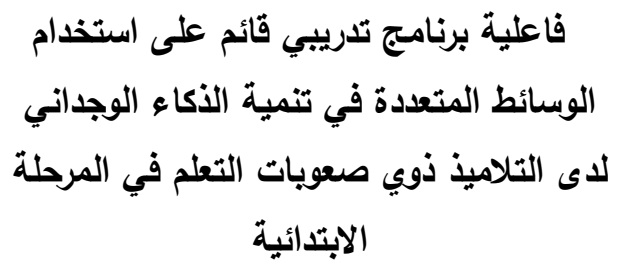 & 1 \\
\hline $\begin{array}{l}223- \\
257\end{array}$ & خالد بكري ضرار & 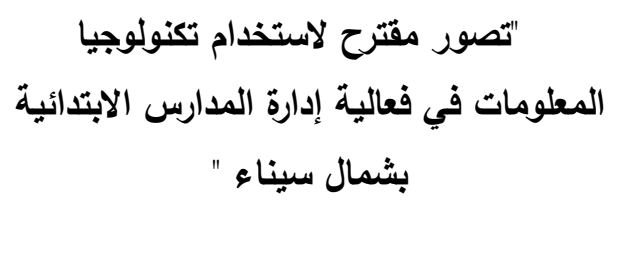 & $r$ \\
\hline $\begin{array}{c}259- \\
292\end{array}$ & 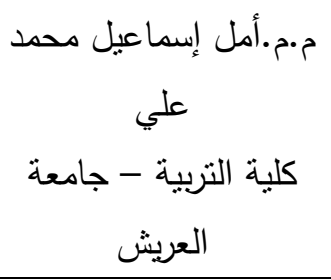 & فاعلية برنامـج قائم على الاعامات التعليمية & $r$ \\
\hline
\end{tabular}




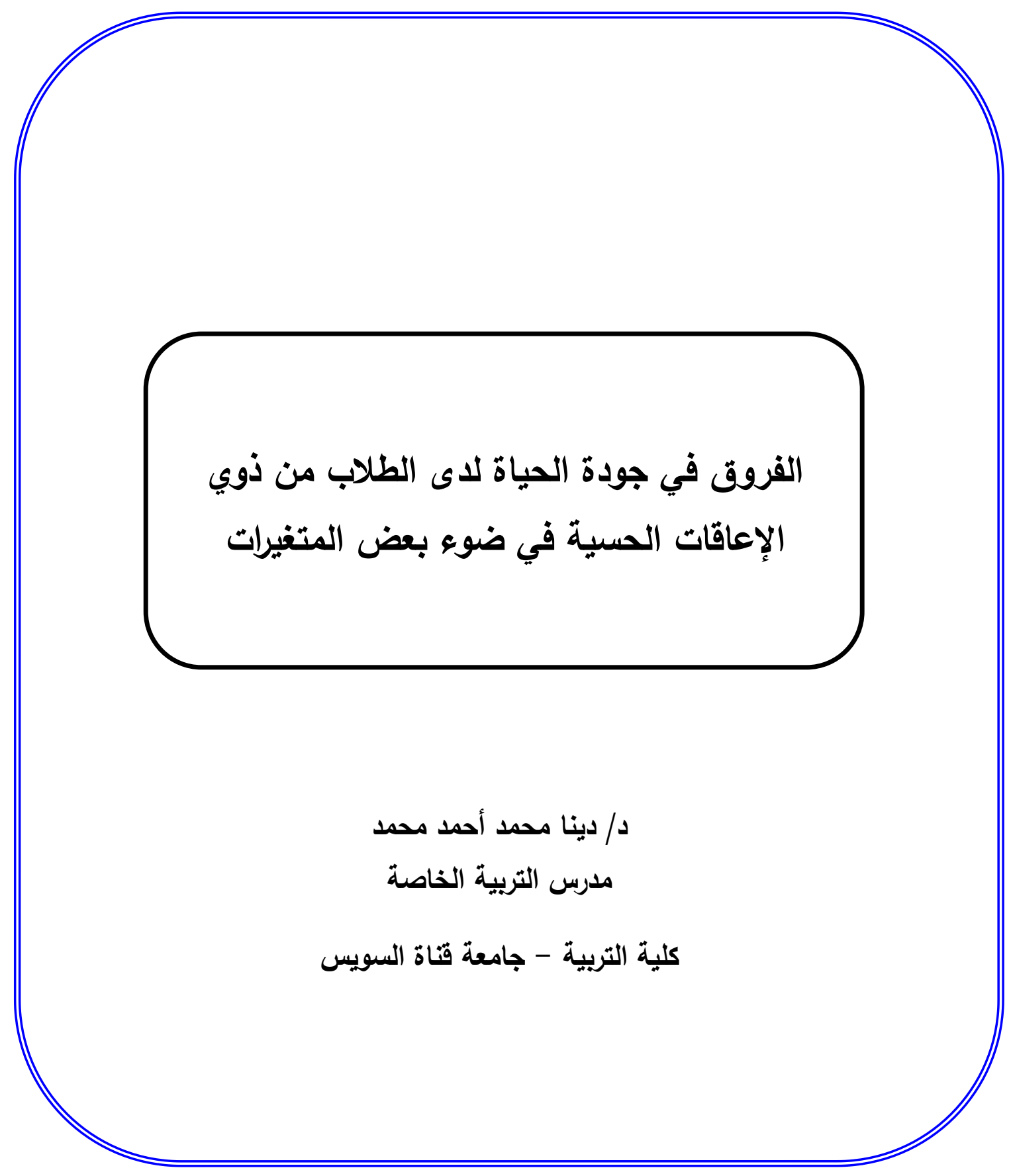




\title{
الفروق في جودة الحياة لاى الطلاب من ذوي الإعاقات الحسية في ضوء بعض المتغيرات
}

\author{
د/ دينا محمد أحمد محمد \\ مدرس التربية الخاصة
}

كلية التربية - جامعة قناة السويس

\section{ملخص الاراسة: - مارة}

هدفت الدراسة الحالية إلى التعرف على مستوى جودة الحياة لدى الطلاب من ذوبي الإعاقات

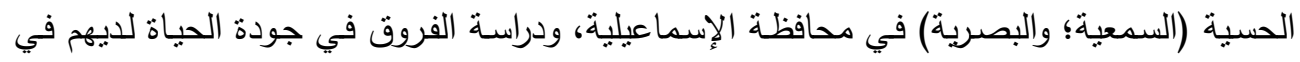



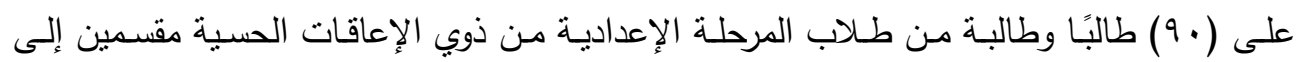

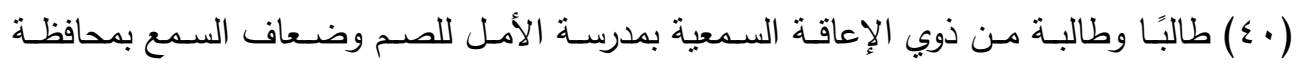



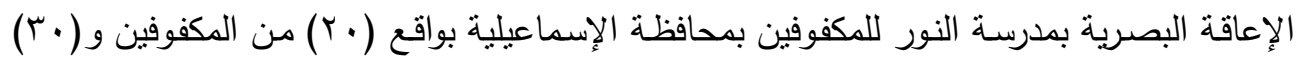

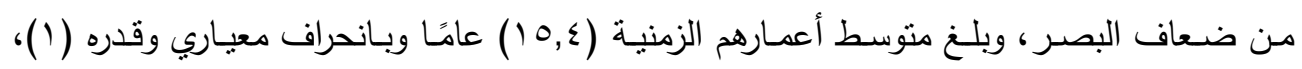

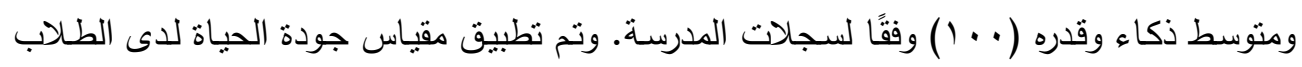

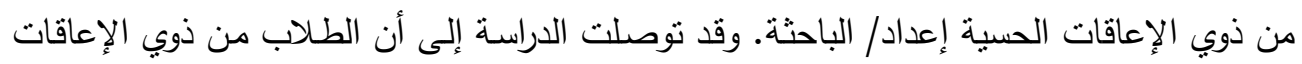

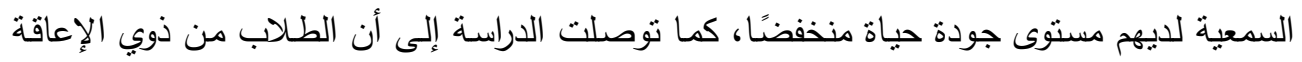

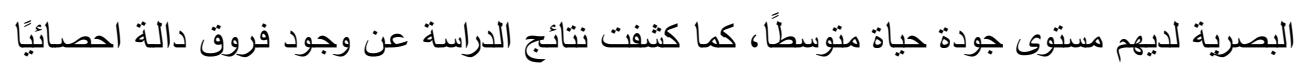

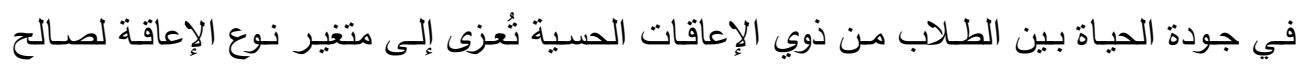

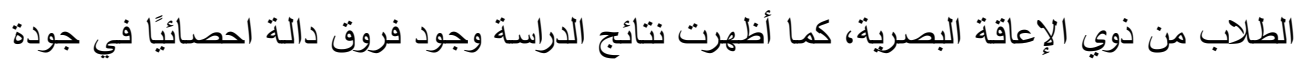

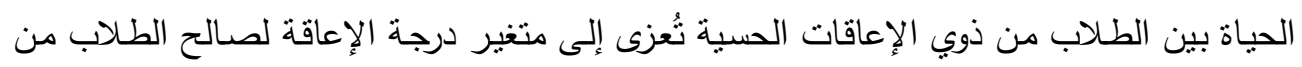

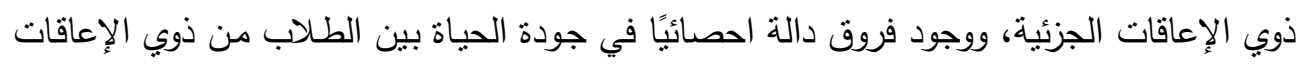

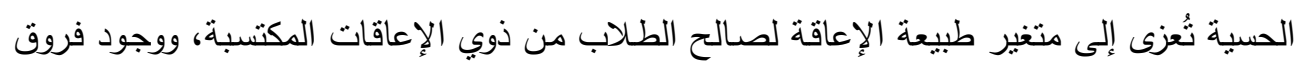

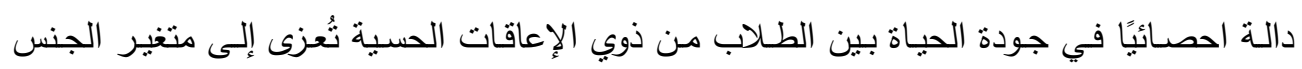

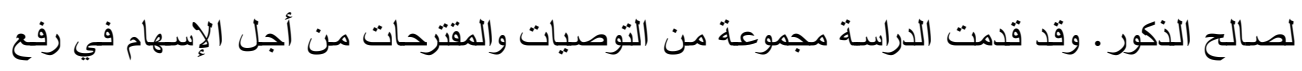
مسنوى وكفاءة جودة الحياة لدى الطلاب من ذوي الإعاقات الحسية (السمعية؛ والبصرية). 
الكلمات العفتاحية: جودة الحياة، الاعاقات الحسية (السمعية؛ والبصرية).

\title{
Differences in the Quality of Life of Students with Sensory Disabilities In view of some variables
}

\author{
Dr. Dina Mohammed Ahmed Mohammed
}

Lecturer of Special Education

Faculty of Education - Suez Canal University

\begin{abstract}
The study was aimed to identifying the quality of life of students with sensory disabilities (audio and visual) in Ismailia Governorate and studying the differences in quality of life in light of the variables of type of disability, degree of disability, nature of disability and gender. The study sample consisted of (90) students of middle school students with sensory disabilities divided into (40) students of middle school students with hearing disabilities at Al Amal School for Deaf and Hearing Impaired in Ismailia Governorate (20) students from the hearing impaired, (20) students from the Deaf and (50) students from the preparatory school with visual disabilities at Al-Noor School for the Blind in Ismailia Governorate with (20) blind students and (30) visually impaired students. The average age was (14.5) years and a standard deviation of (1) years, and the average intelligence (100) according to School records. The study was used The Quality of Life Standard for students with sensory disabilities Scale Prepared by the researcher. The study found that students with hearing disabilities have a low quality of life. The study also found that students with visual impairment have an average quality of life. The results of the study revealed that there were statistically significant differences in the quality of life among students with sensory disabilities Attributable to variable type disability in favor of students with visual impairment, The results of the study also showed statistically significant differences in the quality of life among students with sensory disabilities due to the variable disability degree in favor of students with partial disabilities. There were statistically significant differences in the quality of life among students with sensory
\end{abstract}


disabilities due to the variable nature of disability with statistically significant differences in quality of life among students with sensory disabilities due to sex variable in favor of males. And then provide a set of recommendations and proposals in order to contribute to raising the quality and quality of life of students with sensory disabilities (audio and visual).

Keywords: quality of life, sensory disabilities. 